Article

\title{
The Sensitivity of Urban Heat Island to Urban Green Space-A Model-Based Study of City of Colombo, Sri Lanka
}

\author{
Dikman Maheng ${ }^{1,2,3} \mathbb{C}^{-}$, Ishara Ducton ${ }^{1}$, Dirk Lauwaet ${ }^{4}$, Chris Zevenbergen ${ }^{1,2}$ and \\ Assela Pathirana ${ }^{1, *}$ \\ 1 Dept. of Water Science and Engineering, IHE Delft, Institute for Water Education, 2611 AX Delft, \\ The Netherlands; m.maheng@un-ihe.org (D.M.); ducton.ishara@gmail.com (I.D.); \\ c.zevenbergen@un-ihe.org (C.Z.) \\ 2 Faculty of Civil Engineering and Geosciences, Delft University of Technology, Stevinweg 1, 2628CN Delft, \\ The Netherlands \\ 3 Department of Environmental Engineering, Universitas Muhammadiyah Kendari, Jl. Ahmad Dahlan 10, \\ 93117 Kendari, Indonesia \\ 4 VITO-Flemish Institute for Technological Research, Boeretang 200, 2400 Mol, Belgium; dirk.lauwaet@vito.be \\ * Correspondence: assela@pathirana.net; Tel.: +31-15-215-1854
}

Received: 7 February 2019; Accepted: 18 March 2019; Published: 21 March 2019

\begin{abstract}
Urbanization continues to trigger massive land-use land-cover change that transforms natural green environments to impermeable paved surfaces. Fast-growing cities in Asia experience increased urban temperature indicating the development of urban heat islands (UHIs) because of decreased urban green space, particularly in recent decades. This paper investigates the existence of UHIs and the impact of green areas to mitigate the impacts of UHIs in Colombo, Sri Lanka, using UrbClim, a boundary climate model that runs two classes of simulations, namely urbanization impact simulations, and greening simulations. The urbanization impact simulation results show that UHIs spread spatially with the reduction of vegetation cover, and increases the average UHI intensity. The greening simulations show that increasing green space up to $30 \%$ in urban areas can decrease the average air temperature by $0.1{ }^{\circ} \mathrm{C}$. On the other hand, converting entire green areas into urban areas in suburban areas increases the average temperature from $27.75^{\circ} \mathrm{C}$ to $27.78^{\circ} \mathrm{C}$ in Colombo. This demonstrates the sensitivity of UHI to vegetation cover in both urban and suburban areas. These seemingly small changes are average grid values and may indicate much higher impacts at sub-grid levels.
\end{abstract}

Keywords: green space; urban heat island; UrbClim

\section{Introduction}

Urban heat islands (UHIs) are meteorological impacts of urbanization that cause the air temperature in urban areas to be higher compared to their surrounding non-urban areas. Increasing urban temperature due to urbanization has been observed and studied in cities around the world such as Atlanta [1], Dhaka [2], Ho Chi Minh City [3], Karachi [4], Jakarta [5], Colombo [6], and Tokyo [7]. UHIs may adversely affect physical and mental health [8-10], as well as promote cardiovascular disease and chronic kidney disease [11]. They also have significant effects on energy consumption for cooling of urban buildings [12,13]. Urbanization is the main driver of UHIs, as it leads to massive land-use land-cover (LULC) change, transforming natural urban landscapes from green into grey areas to accommodate housing and public infrastructure. Land transformation has influenced local hydro-climatological conditions, leading to increasing temperature, extreme rainfall events, 
and more flood events due to increased runoff [14-19]. As cities grow due to urbanization, natural elements such as urban green space (UGS) are replaced by high thermal admittance materials which enable the storage of more solar energy, leading to an increase of the surrounding air temperature once it is re-emitted. In case of low vegetation and/or water body in urban areas, solar energy is directly converted into sensible heat instead of latent energy for evapotranspiration and chemical energy in photosynthesis $[20,21]$. This will increase the air temperature, resulting in higher urban temperatures during the evenings and nights compared to those in surrounding non-urban areas with high vegetation covers [22]. Increasing the air temperature in urban areas is also impacted by the geometry of urban areas. Whether urbanization has resulted from expansion or densification, it alters the urban geometry, which potentially impedes the release of longwave radiation or changes the wind direction and increases shortwave energy absorption due to the bouncing around of sunlight in the urban canopy. This condition might result in higher temperatures when the sky view factor (SVF), which is a measure of the openness of the sky to radiative transport, is low [23,24]. Furthermore, the variation of urban temperature can also be influenced by the interaction between urban temperature and air pollution in urban areas where aerosol particles can minimize the incoming shortwave radiation that changes the surface energy budget [25].

Green space is a very subjective concept and has many interpretations [26]. Presently, most cities in the world are greening their cities. For example, the city of Rotterdam in the Netherlands implements the greening concept in city planning and development [27]. Cities can reduce the heat island effect by using green space that provides shadings and open wind-flow paths, which can eliminate the accumulation of heat [28]. This can be practically done by increasing the percentage of green space in urban areas. For example, cities can introduce some of interventions collectively known as sustainable drainage systems, which include green roofs, vegetated swales, and rain gardens [29].

Many studies have looked at the relationship between the intensity of UHIs and UGS with regard to its composition and configuration [14,30-33]. Composition refers to vegetation density and variety of land-cover types, green space size, as well as spatial distribution. Some studies show that the composition of UGS can be more significant to cooling effects, as opposed to its configuration. In Hanoi, Vietnam, the transformation of agricultural land into the impervious (built-up) surface due to urbanization and industrialization between 2003 and 2015 has increased the mean land-surface temperature (MLST). For example, the MLST in urban built-up areas was $43{ }^{\circ} \mathrm{C}$ in 2003, and increased to $46^{\circ} \mathrm{C}$ in 2015. On the other hand, the MLST increase was lower in rural open land where vegetation cover was dominant and water bodies are present. In those areas, the MLST was $36^{\circ} \mathrm{C}$ in 2003 and $38^{\circ} \mathrm{C}$ in 2015, which showed how the vegetation and water contribute to lower surface temperature [32]. Sun and Chen (2017) revealed that $108.86 \mathrm{~km}^{2}$ of the green space in Beijing was lost, which increased LST between $1.6^{\circ} \mathrm{C}$ and $2.2^{\circ} \mathrm{C}$, while $92.5 \mathrm{~km}^{2}$ of the green space expansion had reduced the LST within the range of $-1.1^{\circ} \mathrm{C}$ to $-0.67^{\circ} \mathrm{C}$. These results indicate that changing the levels of green space influence air temperature changes and generate various temperature patterns.

On the other hand, the configuration of UGS is related to spatial pattern as well as the layout of UGS including aggregation, shape, and cohesion of patches [34]. In a particular configuration, UHI intensity can be significantly increased or decreased by different spatial arrangements of UGS [35]. The configuration or spatial distribution of urban green space can influence the flow of energy or the energy exchange among different land-cover features. For example, distribution of green space comprising large tree canopies within a certain distance provides a large cooling effect, while green space with grass should be concentrated to maximize the cooling effect [34]. Hence, the configuration of green space should consider spatial distribution (concentrated or dispersed), the distance between each green space, and shape complexity. Even though there is no significant relationship between the degree of aggregation of green space and mean temperature, it has been found that in a particular space, dispersed configuration or evenly distributed UGS has led to a decrease of the mean temperature [14]. Moreover, available UHI studies are intended to evaluate the impact of existing land-use change on increasing temperature [36-41]. However, the research on mitigation of the existing UHI impacts, 
and in particular projections of increasing temperature due to urban growth and urban planning, are still limited [19,42-49].

UHI studies can be performed using several methods, including field observations, remote sensing [50], and numerical modelling [51]. Field observations are normally made by comparing records from meteorological stations inside and outside of the urban area or using mobile monitoring cars moving between rural fringe and the city center [20]. In addition, advanced computer technology along with high spatial and temporal resolution of satellite imagery has been used to measure UHIs in more detail $[52,53]$. The UHI phenomenon can also be studied by using numerical atmospheric simulation (climate) models [54-60]. The latter approach provides a unique ability to study the response of various land-cover change scenarios on UHI.

In this paper, we present the results of a series of numerical experiments using the urban boundary climate model UrbClim [54] in order to understand the sensitivity of UHIs to UGS in Colombo, Sri Lanka. This study starts with the hypothesis that changes in the quantity and distribution of green space have significant impacts on the spatial and temporal temperature distribution in urban areas. Two groups of green area conditions that represent decreasing and increasing green areas are simulated, and the results are compared with the reference year.

\section{Methodology}

\subsection{Study Area}

Colombo, the capital city of Sri Lanka, is one of the emerging cities in Asia. It has a total city area of $37 \mathrm{~km}^{2}$ and has about 2.4 million inhabitants (Figure 1). The city of Colombo has seen a rapid increase in urbanization in recent decades. It adopted new development programs around a decade ago, triggered by the end of the civil war in the country. According to World Health Organisation (WHO), $9.5 \mathrm{~m}^{2}$ of green area per capita is the minimum requirement for healthy living [61].

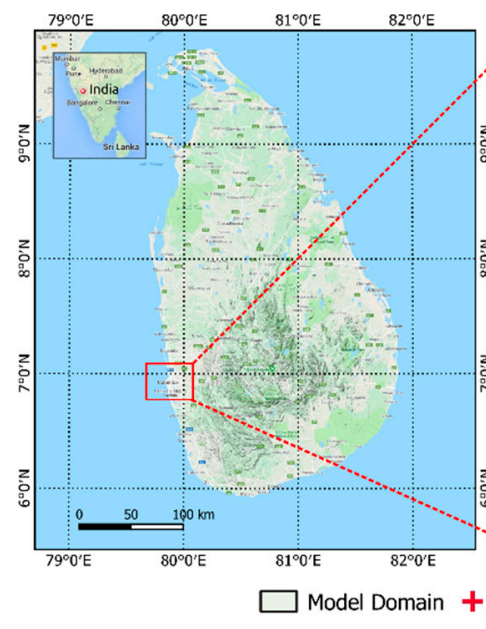

(a)

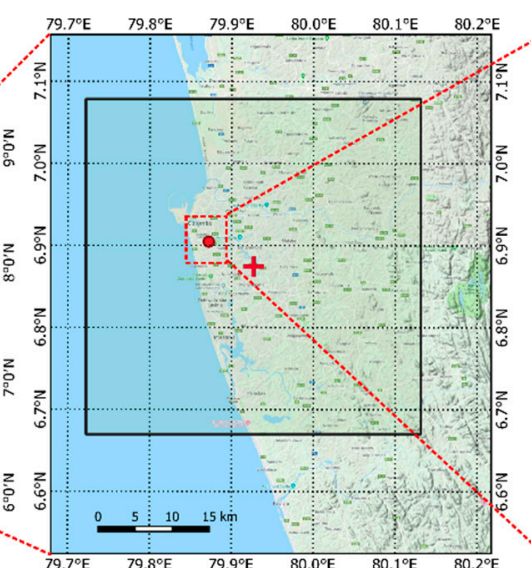

Centre of the model domain

(b)

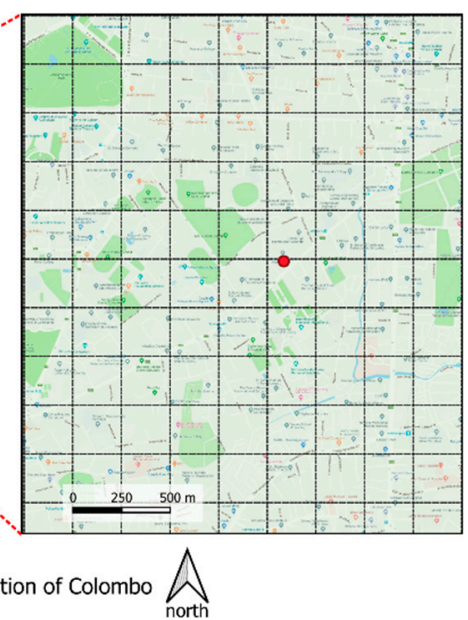

(c)

Figure 1. The location of the study. (a) Sri Lanka (Source: Google maps https:/ /goo.gl/9WypnH); (b) model domain covered with $181 \times 181$ grid cells of $250 \mathrm{~m} \times 250 \mathrm{~m}$ size (grid cells are two dense to show on the figure); (c) The actual grid cells $(250 \mathrm{~m} \times 250 \mathrm{~m})$ around the location of the meteorological station.

The rapid urban development in Colombo has altered the urban landscape by decreasing green areas, resulting in an uneven spatial green area distribution resulting in 34 out of 55 administrative divisions not complying with the WHO standards for the city [62]. Recent observational studies in Colombo reveal that the metropolitan area is experiencing a UHI as there is a significant urban-rural temperature difference, which has not been observed in recent decades $[40,41,63]$. However, it is a 
huge challenge to protect the existing green spaces in the metropolitan area of Colombo from human activities, which can influence the Colombo urban climate.

Colombo is situated in the tropical monsoon climate and experiences average maximum temperatures of about $31^{\circ} \mathrm{C}$ from March to April. The south-western monsoon season that produces large quantities of rainfall is expected from May to September. Average minimum temperatures drop to $22{ }^{\circ} \mathrm{C}$ during the drier months of December to February.

\subsection{UrbClim}

UrbClim is an urban boundary climate model developed by using a land-surface scheme that includes simplified urban physics, coupled with a 3-D atmospheric boundary layer module [54]. The model is designed to simulate the temperature and heat-stress fields using high spatial resolution up to $100 \mathrm{~m}$. UrbClim comprises two main modules, namely surface module and atmospheric module. In the land-surface scheme of UrbClim, an impermeable slab with proper values of emissivity, albedo, and aerodynamic and thermal roughness length is used to represent the urban terrain. The model also takes into account anthropogenic heat fluxes. The surface module simulates the relevant physical interactions between soil, vegetation, and atmosphere following the scheme developed to investigate the interactions between the land-surface and regional atmospheric circulations and climate [64]. UrbClim model makes some major simplifications in the atmospheric model compared to a "standard" mesoscale model such as the weather research and forecast (WRF) model [57], to achieve fast simulations.

The UrbClim performance has been validated by simulating UHI in Toulouse (France), Ghent (Belgium), Antwerp (Belgium), and Bilbao (Spain) [54]. Moreover, UrbClim model performed at an acceptable accuracy with the root mean square error (RMSE) values ranging from $1.6^{\circ} \mathrm{C}$ to $1.9^{\circ} \mathrm{C}$ when the model's outputs are validated with data from 11 ground stations, and has lower computational costs compared to the WRF model when simulating the UHI in Barcelona (Spain) [55]. UrbClim has been implemented to define a new method to assess the UHI in Amsterdam based on the UHI simulation over some cities in Europe [56] and to investigate future UHIs in Delhi, India [65].

\subsection{Model Setup}

Like many limited-area atmospheric models, UrbClim requires two types of data: the geographical data consisting of land cover and topography, and meteorological data which can be obtained from historical re-analyses or large-scale (e.g., global) models. Landsat satellite images for the years 1997 and 2015 were used as the basis for land-cover data. Both geographical (e.g., land use, topography) and meteorological data (initial and lateral boundary conditions) input data sets should have an identical model grid configuration. For this study, a $250 \mathrm{~m}$ spatial resolution as grid spacing for the model was selected. Given the grid spacing, the area of interests was covered by a model domain of $181 \times 181$ square grid that consists of 32,761 grid cells with the center point at $79.9268^{\circ} \mathrm{E}, 6.8745^{\circ} \mathrm{N}$.

For the surface module, land-use data were prepared by using Landsat satellite images from the year 1997 and 2015 selected with the cloud cover less than 10\% and daytime as the main selection criteria. Land-use classification was made by following the local climate zone classification (LCZC) framework developed by the world urban database and access portal tools (WUDAPT) [66]. In the LCZC framework, land-use land cover is classified by considering land definitions from the local climate zone (LCZ) classification designed for urban climate studies. The LCZ framework is based on universal knowledge of built forms and land-cover types, and it is not based on local characteristics such as local topography and climatology of individual cities [67]. Originally, the LCZ framework consists of 17 standard classes divided into ten built types and seven land-cover types. The built type represents urban and non-urban forms identified by height and density of roughness features such as compact high-rise, compact mid-rise, compact low-rise or open low-rise as well as typical urban materials such as paved surface, and low plants or scattered trees in open areas. Moreover, the land-cover type is a classification of surface covers around the roughness which are influenced 
by various factors such as anthropogenic activities and weather patterns [67]. The first application of the LCZ framework for the city of Colombo has been made in a previous study [68] in which a set of sub-classification is developed for the LCZ to adapt the local features, for instance, the compact low-rise zone has mid-rise sub-classification that combines the compact mid-rise and open mid-rise zone, which are some typical land-cover patterns in Colombo.

In this study, the LCZ classes have been re-arranged to accommodate the 15 land-use classes of UrbClim by considering building density and arrangement, the permeability of areas, and building materials. For instance, three compact land uses from the LCZ were classified into urban land-use class in UrbClim. Having established the land-use classes, the LCZC classification tool in SAGA GIS [69] was used to generate two land-use maps from the Landsat satellite images to understand land-use change from 1997 to 2015 in Colombo. The SAGA GIS is a free open source GIS application that provides some plugins for land classification purposes including the LCZC. In SAGA GIS, the LCZC needs training areas that can be prepared in Google Earth (GE). Before running the land classification, Landsat image was resampled from $30 \mathrm{~m}$ to $250 \mathrm{~m}$ by using the nearest neighbor method to meet the UrbClim spatial resolution. In addition, some corrections have been made related to the actual land use and land cover by conducting the field survey and referring to the city development information. Two land-use maps corresponding to 1997 and 2015 (Figure 2) were created, which were based on the UrbClim land-use classes. Other parameter values for the surface module such as albedo and emissivity are specified by following the standard values prepared by the UrbClim development team [54].

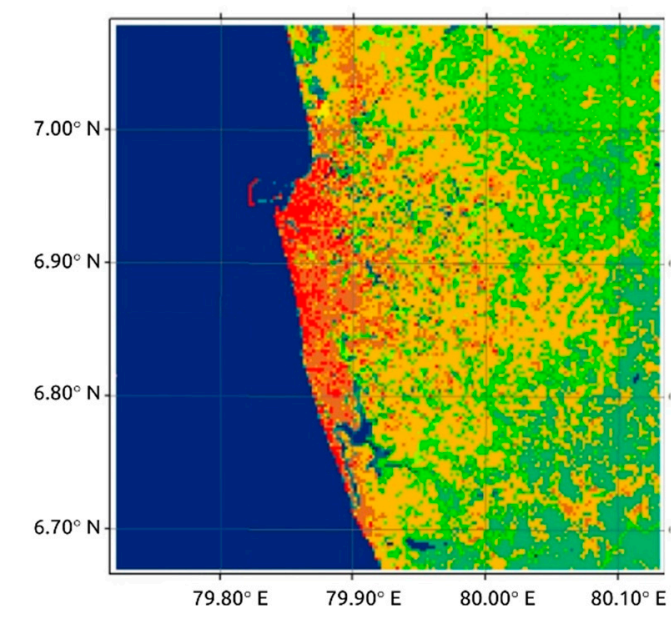

(a)

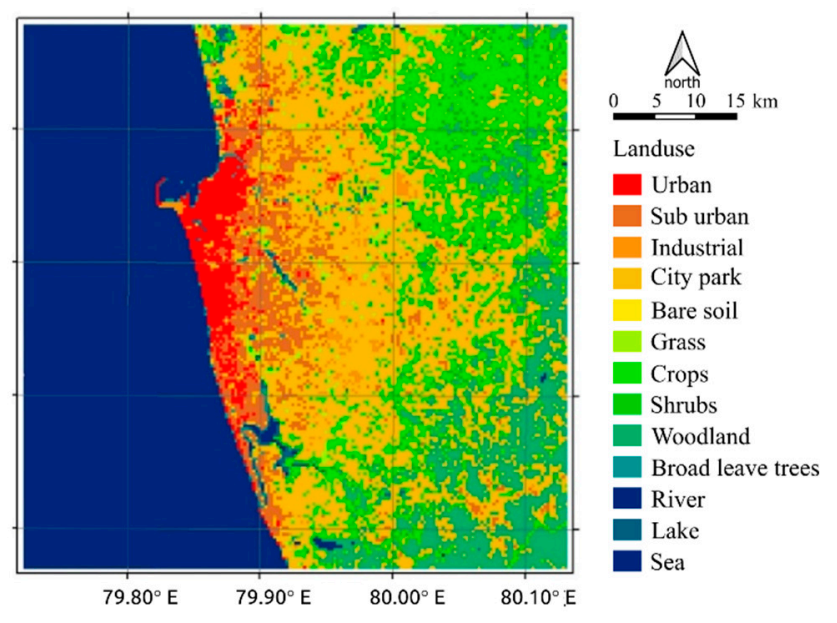

(b)

Figure 2. Land-cover map of (a) 1997; and (b) 2015.

The land-use map of 1997 was considered as the reference land use to calculate the relevant percentage changes by 2015 (see Table 1). Analysis of the land-use change shows that during the 19 -year period, urban areas have been increased by approximately $51 \%$ while suburban areas have been decreased by $15 \%$. It is evident that increased urbanization results in new industrial areas and that a lot of marshes and wetlands located around the city of Colombo have been lost. On the other hand, the proportion of open water bodies decreased with almost $9 \%$, by reclaiming the small lakes located in the vicinity of these marshes/wetlands as urban areas.

Initial and lateral boundary condition data for the atmospheric module were obtained from the ERA-Interim reanalysis of the European center for medium-range weather forecasts (ECMWF) from 1996 to 2015 totally covering a period of 20 years. Such an extended period is needed to obtain statistically valid results. The reanalysis data is obtained by using temporal and spatial resolution parameters. The temporal resolution of data from the ERA-Interim is $3 \mathrm{~h}$, while the spatial resolution is $0.75 \times 0.75$ degree. In this study, the observed air temperature was obtained from the only one 
weather station from the department of meteorological (DoM) located within the area of interest. The station has hourly observations of $2 \mathrm{~m}$ air temperature for 1997 and 2015.

Table 1. Land-use change between 1997 and 2015.

\begin{tabular}{cc}
\hline Land-Use Classes & Land-Use Change (\%) \\
\hline Urban & 50.90 \\
\hline Suburban & -15.50 \\
\hline Industrial & 32.39 \\
\hline City Park & 2.01 \\
\hline Green Areas (Grass, Crops, Shrubs, Woodland, Broadleaf Trees) & -8.94 \\
\hline Open Water (River, Sea, Lake) & -8.97 \\
\hline
\end{tabular}

\subsection{Numerical Simulations}

All numerical experiments were performed for 20 years (1996 through 2015) of reanalysis data as model boundary conditions, changing only the land-use data for each experiment. Further use of the same forcing data would allow us to understand the isolated impact of UHIs because impacts such as global warming had equally affected all numerical experiments. To investigate the sensitivity of the UHI to green area in the city of Colombo, this study was conducted by using two groups of numerical simulations, namely "urbanization impact simulations" and "greening simulations". The urbanization-related simulations were conducted in two parts. The first urbanization impact simulation was performed to identify the existence of the UHI due to land-use change from 1997 to 2015, while the second simulation was intended to investigate the extension of the UHI by expanding urbanization to suburban areas. This is actually a realistic circumstance, as the city of Colombo is expanding over the time and most of the existing suburban areas are converted into urban areas. For instance, the built-up area in Colombo from 1997 to 2017 was expanded beyond the metropolitan area as indicated by an increase in the normalized difference built-up index (NDBI) of suburban areas [40], which was seen to deliver an impact on the UHI in Colombo. Urban expansion was included by assuming a reduction of green space in suburban areas. In this study, the land use of 2015 was used as the baseline for the urban expansion simulation in which the green area in the suburbs was assumed to drop to $0 \%$, which indicated a conversion of entire suburban areas into urban areas. The simulation was performed by providing $10 \%$ green area in suburban areas and comparing the results with the average temperature due to the actual land-use change in 2015. Following similar steps, the simulations were proceeded by providing $5 \%$ and $0 \%$ of green areas in suburban areas.

The greening simulations in this study are assuming various urban greening such as parks, grass, and urban forest. Increasing green areas were made by incrementally increasing the amount of green space in urban areas by $10 \%, 20 \%$, and $30 \%$. The maximum increment of $30 \%$ green area is a practical approach for a city in a developing country such as Sri Lanka. The greening simulations were started by increasing green cover in urban areas by $10 \%$, and comparing the result with the existing condition in 2015. The similar procedure was applied when green areas increased by $20 \%$ and $30 \%$.

The model's performance has been evaluated by comparing $2 \mathrm{~m}$ air temperature from the model's output with observational data from a meteorological station. The difference between both data has been investigated by using the RMSE, the mean absolute error (MAE), and the Pearson correlation coefficient, which have been generally used to evaluate the performance of climate models $[70,71]$ including modelling the UHI in Barcelona [55]. 


\section{Results}

\subsection{Model Validation}

The statistical tests were made to evaluate the model's performance by comparing simulated values from the model and observed data from the meteorological station. The simulated values were extracted from a grid point situated about $100 \mathrm{~m}$ from the measurement station. This is the nearest grid point to the coordinate of the Colombo meteorological station located approximately at latitude $6.9047^{\circ}$ $\mathrm{N}$ and longitude $79.8725^{\circ} \mathrm{E}$ where the air measurement device is positioned at $2 \mathrm{~m}$ above the grass. The nearest grid point was selected since the grid point values are indicating the climate condition of the cell area of $250 \times 250 \mathrm{~m}$, which covers the location of the point measurement. The time series plots for the simulated and observed data is given in Figure 3 that shows $2 \mathrm{~m}$ air temperature values in January 1997 and 2015, respectively. It can be seen that the simulated air temperature is overestimated as confirmed by the RMSE value that is higher than $2{ }^{\circ} \mathrm{C}$.
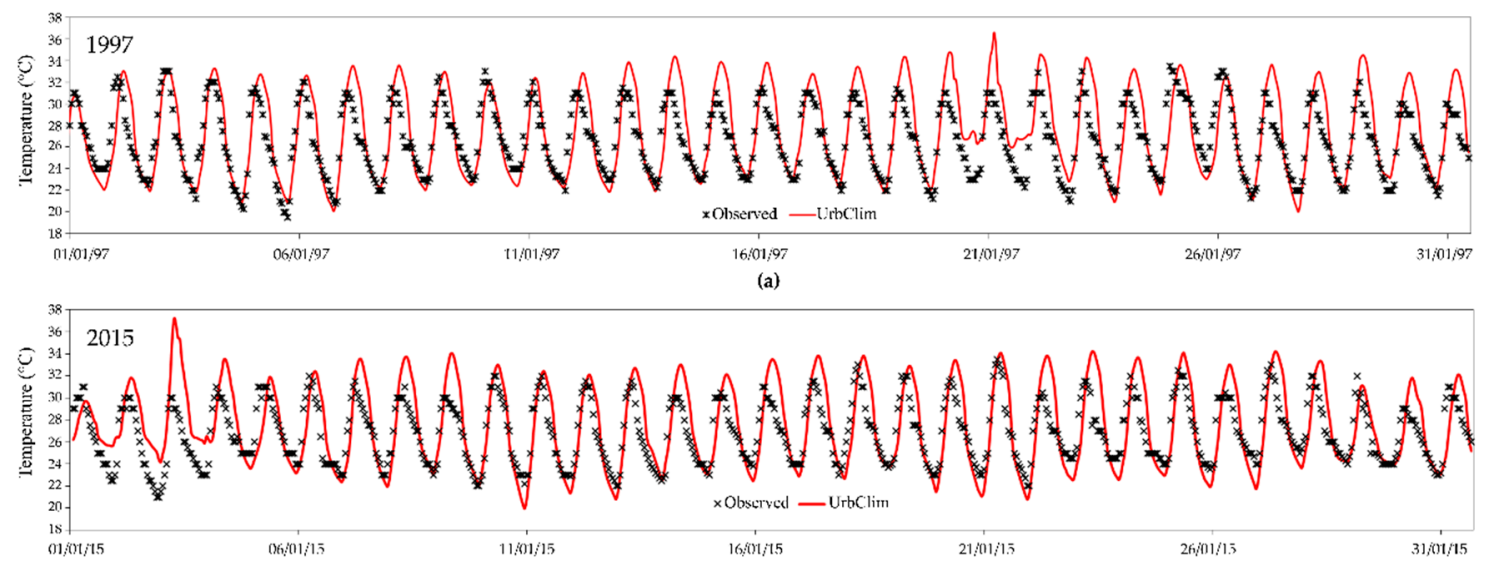

(b)

Figure 3. Simulated and observed daily time series 2 m air temperature of January (a) 1997; (b) 2015.

The overestimate in the simulation is observed at the daytime and earlier at the night time as shown in Figure 4. UrbClim tends to overestimate temperatures after 13:00 with the highest value of $4.06{ }^{\circ} \mathrm{C}$ and $3.96{ }^{\circ} \mathrm{C}$ in 1997 and 2015 , respectively. It clearly shows that the temperature at the grid point at the daytime is higher than at the point measurement. Furthermore, the temperature is well simulated by UrbClim at the night time when the high intensity of UHIs is generally observed. The maximum bias values for the nighttime temperature are $0.58{ }^{\circ} \mathrm{C}$ in 1997 and $0.79{ }^{\circ} \mathrm{C}$ in 2015 .

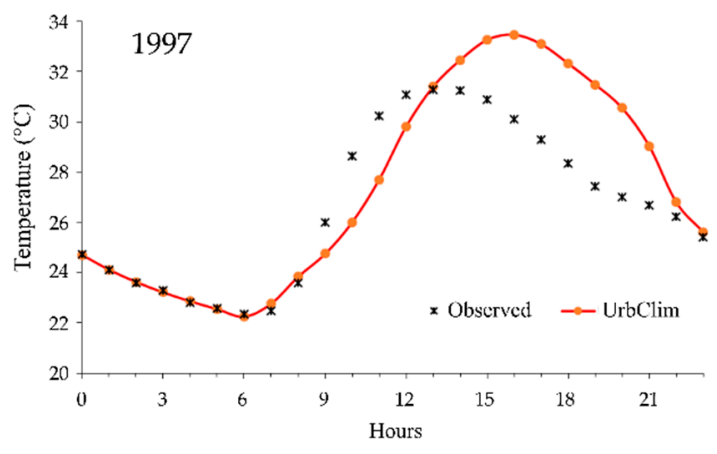

(a)

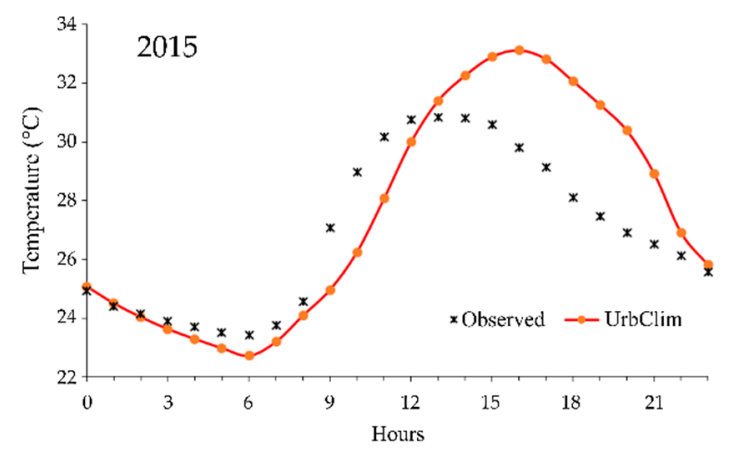

(b)

Figure 4. Mean diurnal variation of 2 m air temperature of January (a) 1997; (b) 2015.

The statistical test showed that the RMSE of the two data sets for 1997 and 2015 were $2.43{ }^{\circ} \mathrm{C}$ and $2.39{ }^{\circ} \mathrm{C}$, respectively. In addition, the MAE test showed that the absolute error values for 1997 
and 2015 were $1.86^{\circ} \mathrm{C}$ and $1.89^{\circ} \mathrm{C}$, respectively. The MAE, which is less than $2{ }^{\circ} \mathrm{C}$, is considered to be acceptable for $2 \mathrm{~m}$ temperature simulations [72]. Furthermore, the Pearson correlation coefficient between simulated and observed data for 1997 and 2015 were 0.82 and 0.79 , respectively as given in Figure 5 . Since these values are within the range of 0.5 and +1 , the correlation check is fairly acceptable compared to the similar test using more than one meteorological stations from the UHI studies with UrbClim in Europe [54].

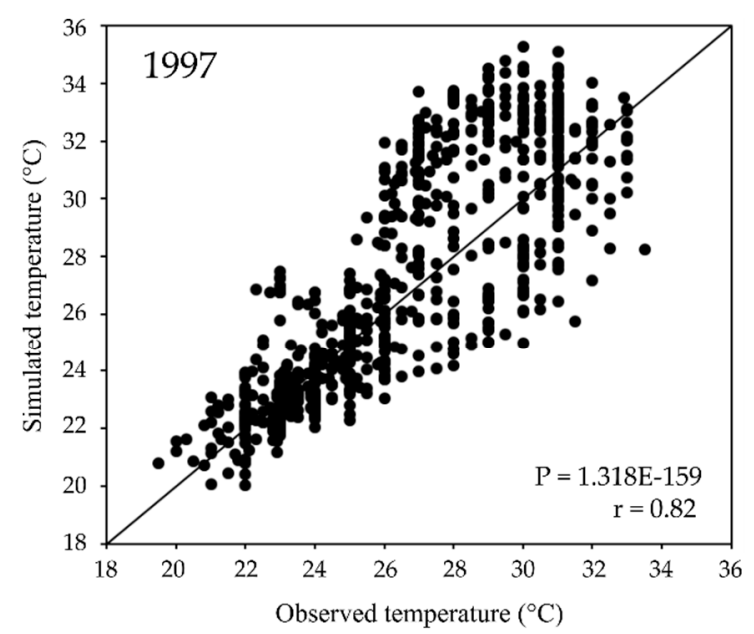

(a)

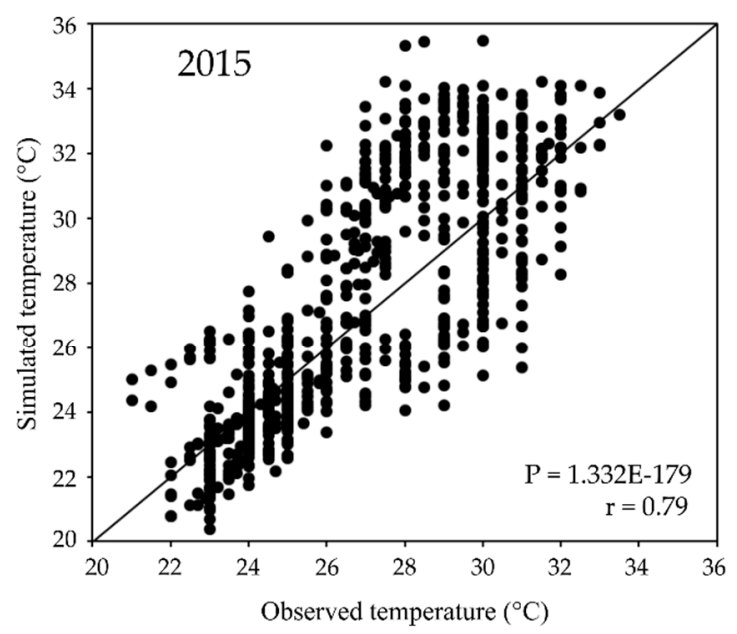

(b)

Figure 5. The Pearson correlation coeffiecint between simulated and observed $2 \mathrm{~m}$ air temperature in January (a) 1997; (b) 2015.

\subsection{Impact of Land-Use Change on UHIs}

The first simulation was conducted to investigate the contribution of the land-use change from 1997 to 2015 on increasing air temperature and development of UHIs. At this step, $2 \mathrm{~m}$ air temperature variations were simulated in relation to the land-use change which showed that decreased green areas from 1997 to 2015 resulted in increased temperatures (see Figure 6).

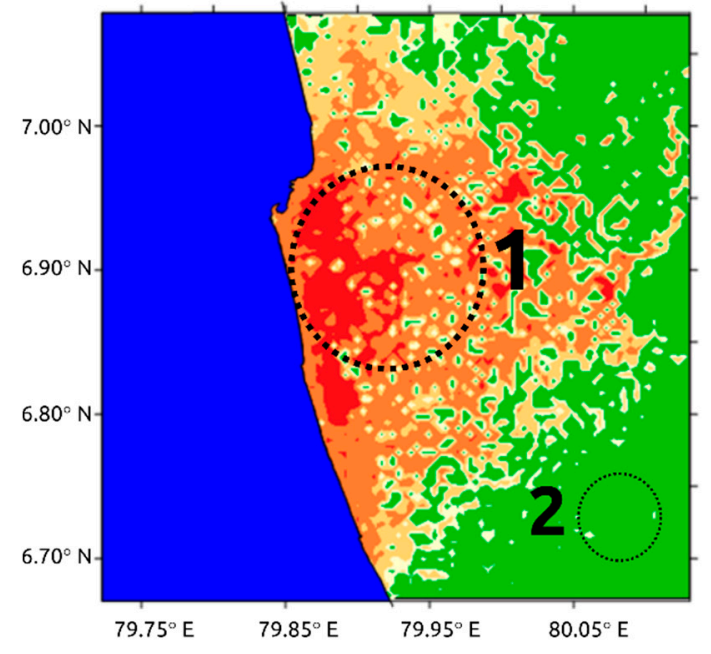

(a)

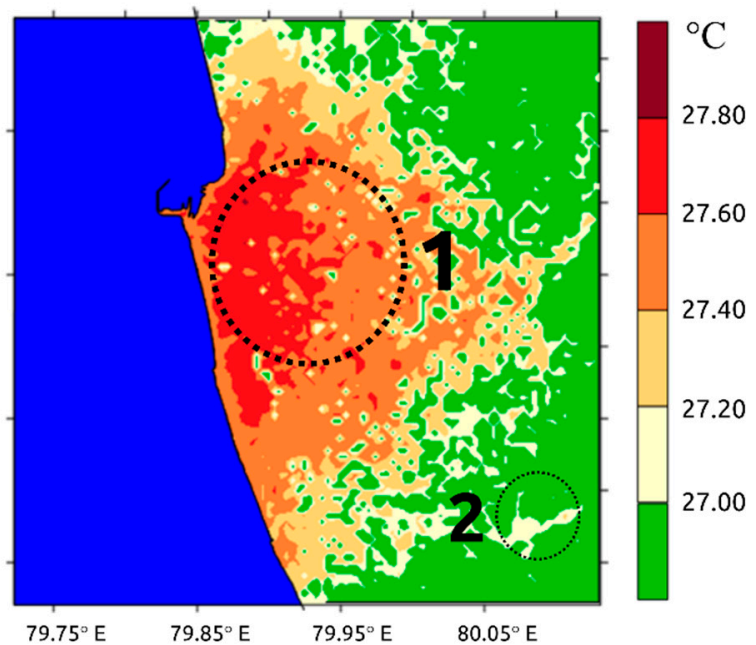

(b)

Figure 6. Spatial $2 \mathrm{~m}$ air temperature distribution in Colombo in (a) 1997; (b) 2015. Area 1: The urban land cover and Area 2: non-urban land cover was used for temperature comparisons.

The maximum temperature increment was found to be $0.8^{\circ} \mathrm{C}$ with the average temperature increment within urban areas recorded to be $0.2{ }^{\circ} \mathrm{C}$. Moreover, the total urban area (observed in 
location 1 in Figure 6) with the average temperature of $27.80^{\circ} \mathrm{C}$ or above, increased from $114.81 \mathrm{~km}^{2}$ in 1997 to $344 \mathrm{~km}^{2}$ in 2015. A significant increase in temperature due to extended urbanization can be seen in the suburban areas indicated in location 2 from Figure 6 the average temperature increased sharply up to $27.20^{\circ} \mathrm{C}$ in 2015 . Furthermore, the results show an increase in the average UHI from $0.45^{\circ} \mathrm{C}$ in 1997 to $0.80{ }^{\circ} \mathrm{C}$ in 2015 . However, the temperature differences between urban and suburban areas in this study were less than found in the study [63] in which the temperature difference ranged from $-0.90{ }^{\circ} \mathrm{C}$ to $4.40^{\circ} \mathrm{C}$.

\subsection{Greening Simulations}

The green scenarios for urban areas (scenario 1-3) were developed by increasing the green area of parks by $10 \%, 20 \%$, and $30 \%$. The spatial distribution of increasing green areas was considering the spatial temperature distribution due to land-use change from 1997 to 2015 . This was made by increasing green area in the area where the temperature ranged between $26{ }^{\circ} \mathrm{C}$ and $27^{\circ} \mathrm{C}$, which were based on the spatial temperature distribution in 2015.

The greening simulations showed that increasing green areas decreased average temperatures as well as UHIs. In general, the highest intensity of UHI is observed at the nighttime particularly during clear sky and calm wind [22]. In this study, it was observed that increasing green areas reduced the average daily temperature in urban areas from $27.75^{\circ} \mathrm{C}$ to $27.67^{\circ} \mathrm{C}$ and decreased the average night time UHI from $1.41^{\circ} \mathrm{C}$ to $1.25^{\circ} \mathrm{C}$. The average night time UHI in this study was based on the temperature from 18:00 to 06:00, while the average day time was based on the temperature from 06:00 to 18:00.

Moreover, increasing green areas also influenced the spatial distribution of urban temperature. It was observed that there was a decrease in the area affected by high temperature (greater than $27.0^{\circ} \mathrm{C}$ ) as indicated in location 1 in Figure 7.

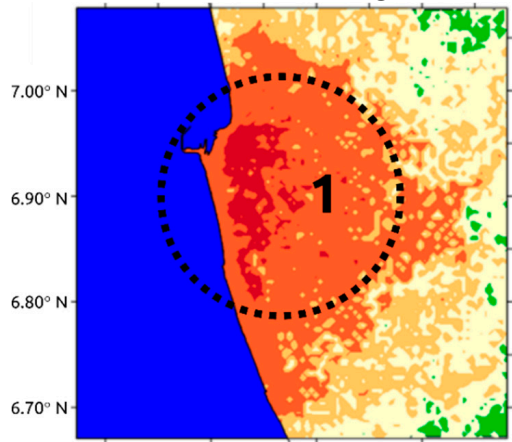

(a)

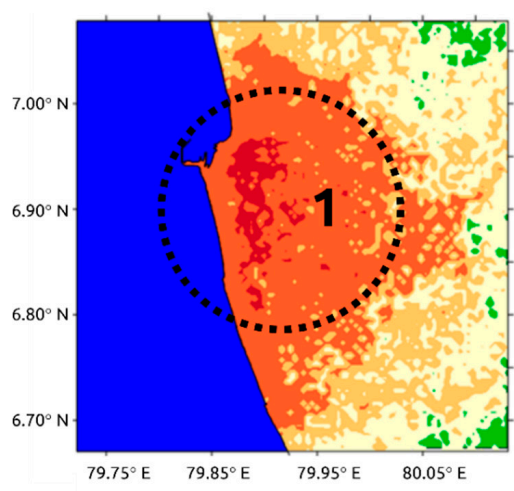

(b)

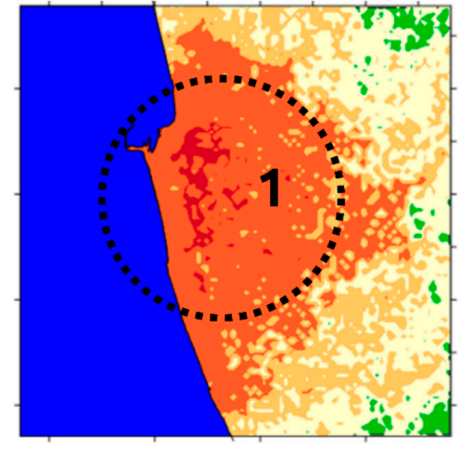

(c)

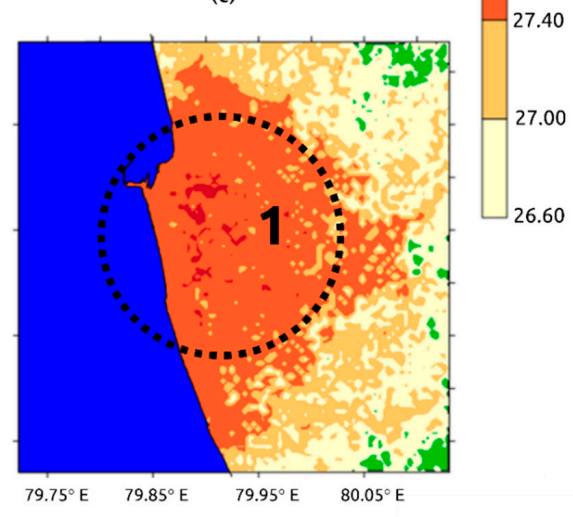

(d)

Figure 7. (a) Average temperature distribution due to land-use change in 2015; (b) Average temperature distribution with $10 \%$ greening; (c) $20 \%$ greening; (d) $30 \%$ greening. 
It shows that the extent of the UHI effects can be reduced by $17.62 \mathrm{~km}^{2}(26 \%), 31.25 \mathrm{~km}^{2}(47 \%)$ and $43.31 \mathrm{~km}^{2}(64 \%)$ when simulating scenarios 1, 2, and 3, respectively. The summary of model's outputs from scenario 1, 2, and 3 are provided in Table 2.

Table 2. Model's outputs for greening scenarios.

\begin{tabular}{cccccc}
\hline Simulation & $\begin{array}{c}\text { Average Temperature } \\
\text { in Urban Areas }\left({ }^{\circ} \mathbf{C}\right)\end{array}$ & $\begin{array}{c}\text { Average Daytime } \\
\text { UHI }\left({ }^{\circ} \mathbf{C}\right)\end{array}$ & $\begin{array}{c}\text { Average Nighttime } \\
\text { UHI }\left({ }^{\circ} \mathbf{C}\right)\end{array}$ & $\begin{array}{c}\text { The Area Experience More } \\
\text { Than } 27.8^{\circ} \mathbf{C} \text { as Avg. } \\
\text { Temperature }\left(\mathbf{k m}^{2}\right)\end{array}$ & $\begin{array}{c}\text { Area } \\
\text { Reduction } \\
\left(\mathbf{k m}^{2}\right)\end{array}$ \\
\hline $\begin{array}{c}\text { Existing } \\
\text { situation }\end{array}$ & 27.75 & 0.26 & 1.41 & 67.12 & \\
\hline Scenario 1 & 27.72 & 0.25 & 1.33 & 49.50 & 35.87 \\
\hline Scenario 2 & 27.70 & 0.24 & 1.28 & 23.81 & 43.25 \\
\hline Scenario 3 & 27.67 & 0.22 & 1.25 & & 43.31 \\
\hline
\end{tabular}

\subsection{Urban Expansion Simulations}

The second simulation of the impact of urbanization was done by assuming that there is urban expansion towards suburban areas. This was made by decreasing the green areas by $10 \%, 5 \%, 0 \%$, in scenario 4, scenario 5, and scenario 6, respectively. The UrbClim's output showed that decreasing green areas in suburban areas had an impact on increasing temperature and UHI in Colombo. The simulation results of the average temperature distribution from the existing situation, scenario 4, 5, and 6 are mapped and shown in Figure 8. It shows that the average daily temperature in urban areas increased from $27.75{ }^{\circ} \mathrm{C}$ to $27.78^{\circ} \mathrm{C}$. As the UHI intensity is higher in the night time, it was observed that urban expansion increased the average nighttime UHI intensity from $1.41^{\circ} \mathrm{C}$ to $1.44{ }^{\circ} \mathrm{C}$ when the vegetation cover in the suburban region was reduced.

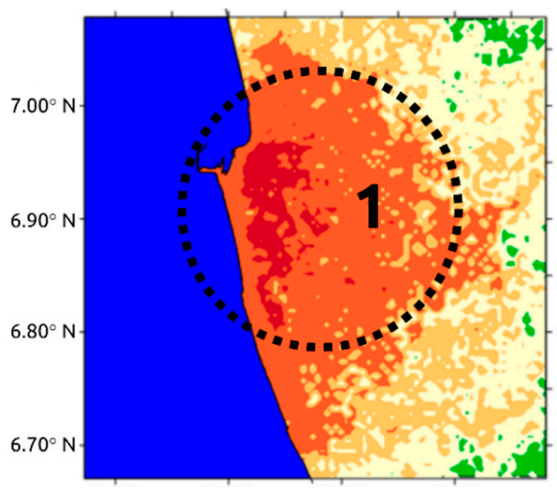

(a)

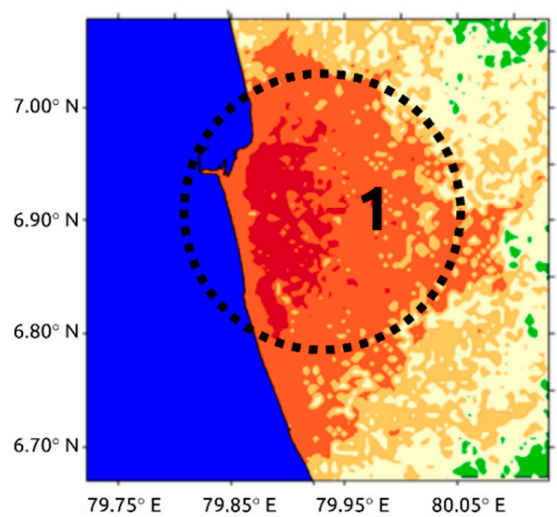

(b)

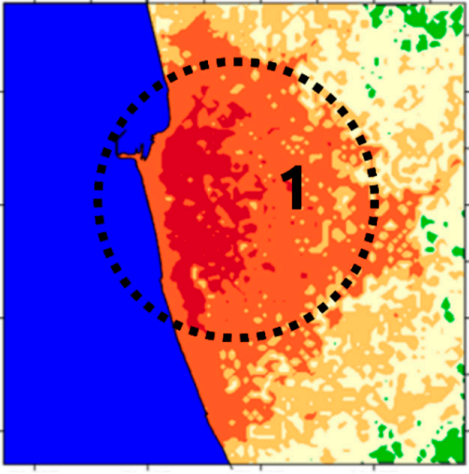

(c)

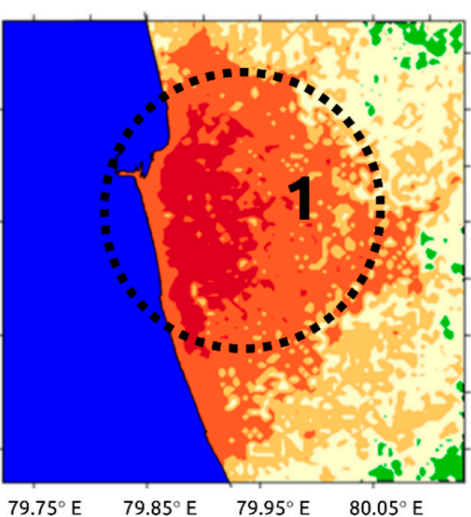

(d)
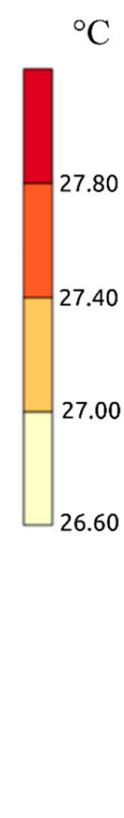

Figure 8. (a) Average temperature distribution due to land-use change in 2015; (b) Providing only 10\% greening; (c) Providing by 5\%; (d) No green areas. 
Moreover, an increase in areas affected by high UHI intensity was observed. The areas experiencing average high temperature increased by $35.63 \mathrm{~km}^{2}(53 \%), 52.01 \mathrm{~km}^{2}(77 \%)$, and $75.19 \mathrm{~km}^{2}$ $(112 \%)$ when UrbClim simulated air temperatures using scenario 4, 5, and 6, respectively. The summary of model's outputs for urban expansion simulations are given in Table 3.

Table 3. Model's outputs for urban expansion scenarios.

\begin{tabular}{|c|c|c|c|c|c|}
\hline Simulation & $\begin{array}{l}\text { Average Temperature } \\
\text { in Urban Areas }\left({ }^{\circ} \mathrm{C}\right)\end{array}$ & $\begin{array}{l}\text { Average Daytime } \\
\text { UHI }\left({ }^{\circ} \mathrm{C}\right)\end{array}$ & $\begin{array}{c}\text { Average Nighttime } \\
\text { UHI }\left({ }^{\circ} \mathrm{C}\right)\end{array}$ & $\begin{array}{l}\text { The Area with Avg. Temperature } \\
\text { More Than } 27.8^{\circ} \mathrm{C}\left(\mathrm{km}^{2}\right)\end{array}$ & $\begin{array}{l}\text { Increased } \\
\text { Areas }\left(\mathrm{km}^{2}\right)\end{array}$ \\
\hline $\begin{array}{l}\text { Existing } \\
\text { situation }\end{array}$ & 27.75 & 0.26 & 1.41 & 67.12 & \\
\hline Scenario 4 & 27.76 & 0.22 & 1.42 & 102.75 & 35.63 \\
\hline Scenario 5 & 27.77 & 0.22 & 1.42 & 119.13 & 52.01 \\
\hline Scenario 6 & 27.78 & 0.22 & 1.44 & 142.31 & 75.19 \\
\hline
\end{tabular}

\section{Discussion}

The simulation results above show that changes in the quantity and distribution of UGS in Colombo affect the spatial and temporal temperature distribution. Between 1997 and 2015, urban areas in Colombo increased by $51 \%$. These land-use changes along with global climate change have increased the average temperature by $0.2^{\circ} \mathrm{C}$ in urban areas. However, global climate change alone has more contribution in increasing the average temperature in rural areas or new urban areas [49]. Moreover, the average UHI intensity also increased from $0.45^{\circ} \mathrm{C}$ in 1997 to $0.80{ }^{\circ} \mathrm{C}$ in 2015 . The main factor contributing to increasing urban temperature is that the decreased green space resulted in a low evapotranspiration rate while most of the solar energy was converted to sensible heat, or stored and slowly released during the night $[51,73]$. This condition can be observed in Colombo particularly in impervious areas where green space coverage is low and at the same time surface materials with high thermal admittance such as concrete, asphalt, or black roof are dominant [40]. Those materials can accumulate heat more intensely leading to the formation of the UHI. Moreover, a decrease of the water bodies, as well as low soil moisture can also contribute to more sensible heat since less water was available for evapotranspiration [74].

Another factor that has to be considered in increasing the average temperature in Colombo is the low SVF [6]. The SVF has an inverse relation to shading effects at which the low SVF indicates a less shading effect available and vice versa. The low SVF contributes to the increased urban temperature of Colombo particularly in urban areas where the compact mid-rise and high-rise zones increased between 2010 and 2017 [68].

The average temperature was reduced in the greening scenarios as demonstrated by simulating the regeneration of the vegetation cover of 1997 in 2015, which was done by providing up to $30 \%$ of green space coverage in urban areas. The model indicated that increasing the quantity of green space decreased the average temperature as well as both the day time and the night time UHI particularly within the area where built-up and impervious areas were re-converted to green space. These changes reduced the average temperature possibly through one or a combination of ecosystem services provided by green areas such as intercepting solar radiation, evapotranspiration, and modifying air movement [75]. The sensitivity of UHIs to UGS from the greening simulations also showed that an appropriate quantity and distribution of green space can provide cooling effects to lower the air temperature [14] through evapotranspiration [76], which can be explained by the fact that approximately $1000 \mathrm{MJ}$ is consumed by a single tree for heat energy in the transpiration process [28]. The decreased temperature in urban areas can influence temperature differences between urban and suburban areas that lead to prevent UHI formation.

Moreover, the urbanization extension increased the average temperature as well as the extent of the affected areas. Extension of the built-up areas was represented by reducing the amount of available green space to $0 \%$ in suburban areas. From the simulations, it was shown that the expansion of urbanization towards the suburban areas had caused more regions to be affected by increased 
temperature (higher than $27^{\circ} \mathrm{C}$ ), although increasing the average temperature was small $\left(0.03^{\circ} \mathrm{C}\right)$. Increasing the average temperature as the impacts of future urban expansion have been investigated in some Asian cities, for example in Ho Chi Minh City [49], where the impact of urbanization on increasing temperature can be approximately $20-30 \%$ of global warming. Future urbanization might not significantly increase the urban temperature as well as the intensity of UHIs but it might extend the UHI [77]. The increased average temperature was mainly a result of the decreasing green space and reduced or loss of the water body as discussed above. However, there is a situation in the real world where the increased temperature can also be influenced by the energy exchange between adjacent areas. The exchange can happen through advection of sensible heat from urban to suburban areas [78]. For instance, increased air temperature about $1 \mathrm{~K}$ between 1970 and 2000 in the Old City, a built-up historical area in Jakarta, was influenced by high temperature from adjacent areas where new urban development took place [5].

Different size and spatial distribution of the green space show influence on the average temperature. The simulation results show that the variation in spatial temperature distribution is consistent with findings from previous UHI studies in Colombo which show temperature differences between urban and suburban areas $[6,40,41,63]$. Moreover, the simulated temperature in UrbClim is the average temperature that is calculated based on grid values. In reality, the value should be considered only as an indication of high temperatures from specific places such as a car park, which influences ambient temperature in the immediate surrounding. Such sub-grid scale effects are not be captured by the current model with $250 \mathrm{~m}$ grids. However, the indication from UrbClim simulation is useful to understand UHIs particularly when a UHI study is started by having limited information about urban detail such as urban canopy geometry [54].

Furthermore, the average UHI intensity in this study, which are $0.26{ }^{\circ} \mathrm{C}$ in the daytime and $1.41{ }^{\circ} \mathrm{C}$ in the night time, seem to be lower than that in another Asian city such as Delhi where the average urban-rural temperature differences can be more than $4{ }^{\circ} \mathrm{C}$ [65]. The lower UHI intensity in Colombo is related to the regional climate characteristics. Located in the tropical monsoon climate, Colombo receives the amount of rainfall over the year with total annual precipitation about $2500 \mathrm{~mm}$. The influence of precipitation to the UHI intensification is also observed in Rennes, France, where the average UHI intensity at the daytime and the night time are $0.5^{\circ} \mathrm{C}$ and $2{ }^{\circ} \mathrm{C}$, respectively [79].

However, it was noticed that UrbClim model tends to overestimate air temperature values particularly when the results for January 1997 and 2015 were compared against the observed air temperature. The bias between the simulated and the observed temperature was related to the nature of data since the correlation test was made by comparing the point source observation data with the spatially averaged grid values from the model. The bias is also influenced by the difference in land-use classes. The land use of the grid point in UrbClim is classified as the urban class while the point measurement is located within a small grassy patch of about $50 \mathrm{~m} \times 50 \mathrm{~m}$ size, which is not large enough to influence the land cover of the model grid. Located in the urban land-use classes in the simulation, the temperature at the grid point during the daytime is higher than at the point measurement and it is decreased slowly until the evening. Both these observations, namely, the higher peak and slower drop in temperature in the urban areas compared to green (e.g., grass) areas is expected. Urban areas absorb higher amount of thermal energy during the daytime and is slowly released in the evening [51]. This overestimate results from UrbClim were also observed in the UHI study for the city of Ghent (Belgium) and Bilbao (Spain) with the correlation coefficient between simulated and observed data were recorded as 0.95 and 0.90 , respectively [54]. This therefore can be considered as a consistent issue with the UrbClim model.

Compared to some similar cases one of the obvious limitations of the present study is the fact that the availability of only one weather station within the study area. This is largely an unavoidable issue not only in this case study but many potential future studies in data-poor environments, unless data is augmented by techniques such as low-cost citizen observatories [80]. 


\section{Conclusions}

In the present study, we have investigated the influence of green space on the spatial and temporal distribution of urban temperature as well as UHIs. The investigation is made by changing the size and distribution of green space using two sets of simulation named "urbanization impact simulations" and "greening simulations". These simulations are conducted using UrbClim, a boundary urban climate model, with a spatial resolution of 250 meters and two different land-use maps from 1997 and 2015, which are generated from Landsat images by using the LCZ framework.

It is observed that urbanization alters urban landscape from green to grey environments, and that affects the spatial temperature distribution. Two urbanization impact simulations show that the decreasing green space both in urban and suburban areas can increase the average temperature as well as extend areas affected by high temperature. On the other hand, the greening simulations show that the increasing size of green space can decrease average air temperature and it can minimize the spread of high temperature. Moreover, increasing urban temperature and UHI can be influenced by other aspects such as the SVF and urban morphology, which are not considered in this study.

It should be noted that while this study has used a relatively finer resolution of $250 \mathrm{~m}$ (in comparison to typical mesoscale atmospheric simulation studies), still the temperature values produced by the model are grid-average values that ignore a lot of sub-grid-scale heterogeneity. Therefore, the seemingly moderate increases in temperature reported at grid-average scale should only be considered as a symptom of (much higher) sub-grid-scale temperature variations. Actual temperature hotspots may demonstrate temperature increases often much larger than the grid-average value. Further studies, ideally in conjunction with field observations, should be done to establish such sub-grid-scale temperature relationships.

The numerical urban climate simulations with UrbClim using the variations of green space size and distribution show that the spatial and temporal distribution of urban temperature is sensitive to the size and distribution of green space. It can be seen from the variations in temperature differences between urban and suburban areas where green space is modified. Moreover, a numerical experiment that combines various scenarios including land-use change, mitigation and adaptation (greening scenarios), and urban expansion, is still necessary while UHI studies combine those scenarios are limited. Hence, it is relevant to establish the relationship between green space, urban planning, and UHIs, and ascertain the sensitivity of the UHI effect to the presence of green space.

Author Contributions: Methodology, I.D., D.L., A.P.; Investigation, D.M., I.D., A.P.; Software, D.L.; Validation, D.M. and I.D.; Formal Analysis, I.D.; Writing-Original Draft, D.M.; Writing-Review and Editing, D.M., D.L., C.Z., A.P.; Visualization, D.M. and I.D.

Funding: This work is funded by multiple sources including the NUFFIC master scholarship for Ishara Ducton and the BUDI-LPDP (Indonesia Endowment Fund for Education) PhD scholarship for Dikman Maheng.

Acknowledgments: The work described in this paper is a part of MSc thesis work conducted by Ishara Ducton for the partial fulfilment of requirements for the Master of Science degree at the IHE Delft Institute for Water Education, Delft, The Netherlands. The authors also acknowledge the use of data from ECMWF and USGS as well as VITO that provides the main component of UrbClim and the downscaled meteorological data from the ECMWF. The UrbClim's simulations were done by using the high performance computing provided by SURFsara, the Netherlands. The authors thank Mohanasundar Radakrishnan for the English correction.

Conflicts of Interest: The authors declare no conflict of interest.

\section{References}

1. Fu, P.; Weng, Q. Responses of urban heat island in Atlanta to different land-use scenarios. Theor. Appl. Climatol. 2017, 1-13. [CrossRef]

2. Ahmed, S. Climate risks in megacities of the global south: Focus on Dhaka, Bangladesh. In The "State of DRR at the Local Level" A 2015 Report on the Patterns of Disaster Risk Reduction Actions at Local Level; UNISDR: Geneva, Switzerland, 2015; pp. 1-11. 
3. Doan, Q.-V.; Kusaka, H. Numerical study on regional climate change due to the rapid urbanization of greater Ho Chi Minh City's metropolitan area over the past 20 years. Int. J. Climatol. 2016, 36, 3633-3650. [CrossRef]

4. Uz Zaman Chaudhry, Q.; Rasul, G.; Kamal, A.; Ahmad Mangrio, M.; Mahmood, S. Technical Report on Karachi Heatwave June 2015; Government of Pakistan Ministry of Climate Change: Karachi, Pakistan, 2015.

5. Tokairin, T.; Sofyan, A.; Kitada, T. Effect of land use changes on local meteorological conditions in Jakarta, Indonesia: Toward the evaluation of the thermal environment of megacities in Asia. Int. J. Climatol. 2010, 30, 1931-1941. [CrossRef]

6. Vidanapathirana, M.; Perera, N.G.R.; Emmanuel, R. Microclimatic impacts of high-rise cluster developments in Colombo, Sri Lanka. In "Design that Cares-Inter Disciplinary Approach to Making Built Environments Efficient and Meaningful": Proceedings of the 10th International Conference of Faculty of Architecture Research Unit (FARU); Rajapaksa, U., Ed.; University of Moratuwa: Moratuwa, Sri Lanka, 2017; pp. 1-12.

7. Matsumoto, J.; Fujibe, F.; Takahashi, H. Urban climate in the Tokyo metropolitan area in Japan. J. Environ. Sci. 2017, 59, 54-62. [CrossRef] [PubMed]

8. Steul, K.; Schade, M.; Heudorf, U. Mortality during heatwaves 2003-2015 in Frankfurt-Main - the 2003 heatwave and its implications. Int. J. Hyg. Environ. Health 2018, 221, 81-86. [CrossRef] [PubMed]

9. Xu, Z.; Cheng, J.; Hu, W.; Tong, S. Heatwave and health events: A systematic evaluation of different temperature indicators, heatwave intensities and durations. Sci. Total Environ. 2018, 630, 679-689. [CrossRef] [PubMed]

10. Kasai, M.; Okaze, T.; Mochida, A.; Hanaoka, K. Heatstroke risk predictions for current and near-future summers in Sendai, Japan, based on mesoscale WRF simulations. Sustainability 2017, 9, 1467. [CrossRef]

11. Watts, N.; Amann, M.; Ayeb-Karlsson, S.; Belesova, K.; Bouley, T.; Boykoff, M.; Byass, P.; Cai, W.; Campbell-Lendrum, D.; Chambers, J.; et al. The Lancet Countdown on health and climate change: From 25 years of inaction to a global transformation for public health. Lancet 2017, 6736. [CrossRef]

12. Hirano, Y.; Fujita, T. Evaluation of the impact of the urban heat island on residential and commercial energy consumption in Tokyo. Energy 2012, 37, 371-383. [CrossRef]

13. Kolokotroni, M.; Ren, X.; Davies, M.; Mavrogianni, A. London's urban heat island: Impact on current and future energy consumption in office buildings. Energy Build. 2012, 47, 302-311. [CrossRef]

14. Bao, T.; Li, X.; Zhang, J.; Zhang, Y.; Tian, S. Assessing the distribution of urban green spaces and its anisotropic cooling distance on urban heat island pattern in Baotou, China. ISPRS Int. J. Geo-Inf. 2016, 5, 12. [CrossRef]

15. Huong, H.T.L.; Pathirana, A. Urbanization and climate change impacts on future urban flooding in Can Tho city, Vietnam. Hydrol. Earth Syst. Sci. 2013, 17, 379-394. [CrossRef]

16. Pachauri, R.K.; Reisinger, A. Contribution of Working Groups I, II and III to the Fourth Assessment Report of the Intergovernmental Panel on Climate Change; IPCC: Geneva, Switzerland, 2007.

17. Zope, P.E.; Eldho, T.I.; Jothiprakash, V. Hydrological impacts of land use land cover change and detention basins on urban flood hazard: a case study of Poisar River basin, Mumbai, India. Nat. Hazards 2017, 1-17. [CrossRef]

18. Lin, C.Y.; Chen, W.C.; Chang, P.L.; Sheng, Y.F. Impact of the urban heat island effect on precipitation over a complex geographic environment in northern Taiwan. J. Appl. Meteorol. Climatol. 2011, 50, 339-353. [CrossRef]

19. Pathirana, A.; Denekew, H.B.; Veerbeek, W.; Zevenbergen, C.; Banda, A.T. Impact of urban growth-driven landuse change on microclimate and extreme precipitation-A sensitivity study. Atmos. Res. 2014, 138, 59-72. [CrossRef]

20. Hidalgo, J.; Masson, V.; Baklanov, A.; Pigeon, G.; Gimeno, L. Advances in urban climate modeling. Ann. N. Y. Acad. Sci. 2008, 1146, 354-374. [CrossRef] [PubMed]

21. Wallace, J.M.; Hobbs, P.V. Atmospheric Science, an Introductory Survey; Elsevier: Amsterdam, The Netherlands, 2006; Volume 7, ISBN 0-12-732951-X.

22. U.S. Environmental Protection Agency. Reducing Urban Heat Islands: Compendium of Strategies Urban Heat Island Basics; U.S. Environmental Protection Agency: Washington, DC, USA, 2008.

23. Brown, M.J.; Grimmond, S. Sky View Factor Measurements in Downtown Salt Lake City-Data Report for the DOE CBNP URBAN Experiment; Los Alamos National Laboratory: Los Alamos, NM, USA, 2001; Volume 836.

24. Svensson, M.K. Sky view factor analysis - implications for urban air temperature differences. Meteorol. Appl. 2004, 11, 201-211. [CrossRef] 
25. Li, H.; Meier, F.; Lee, X.; Chakraborty, T.; Liu, J.; Schaap, M.; Sodoudi, S. Interaction between urban heat island and urban pollution island during summer in Berlin. Sci. Total Environ. 2018, 636, 818-828. [CrossRef] [PubMed]

26. Taylor, L.; Hochuli, D.F. Defining greenspace: Multiple uses across multiple disciplines. Landsc. Urban Plan. 2017, 158, 25-38. [CrossRef]

27. Rotterdam, C. Rotterdam Programme on Sustainability and Climate Change 2015-2018; City of Rotterdam: Rotterdam, The Netherlands, 2015.

28. Bolund, P.; Hunhammar, S. Ecosystem services in urban areas. Ecol. Econ. 1999, 29, 293-301. [CrossRef]

29. Charlesworth, S.M. A review of the adaptation and mitigation of global climate change using sustainable drainage in cities. J. Water Clim. Chang. 2010, 1, 165-180. [CrossRef]

30. Forman, R.T.T. Landscape Mosaic: The Ecology of Landscape and Regions; Cambridge University Press: New York, NY, USA, 1995.

31. Sun, R.; Chen, L. Effects of green space dynamics on urban heat islands: Mitigation and diversification. Ecosyst. Serv. 2017, 23, 38-46. [CrossRef]

32. Tran, D.X.; Pla, F.; Latorre-Carmona, P.; Myint, S.W.; Caetano, M.; Kieu, H.V. Characterizing the relationship between land use land cover change and land surface temperature. ISPRS J. Photogramm. Remote Sens. 2017, 124, 119-132. [CrossRef]

33. Zhou, W.; Huang, G.; Cadenasso, M.L. Does spatial configuration matter? Understanding the effects of land cover pattern on land surface temperature in urban landscapes. Landsc. Urban Plan. 2011, 102, 54-63. [CrossRef]

34. Sodoudi, S.; Zhang, H.; Chi, X.; Müller, F.; Li, H. The influence of spatial configuration of green areas on microclimate and thermal comfort. Urban For. Urban Green. 2018, 34, 85-96. [CrossRef]

35. Xiao, X.D.; Dong, L.; Yan, H.; Yang, N.; Xiong, Y. The influence of the spatial characteristics of urban green space on the urban heat island effect in Suzhou Industrial Park. Sustain. Cities Soc. 2018, 40, 428-439. [CrossRef]

36. Connors, J.P.; Galletti, C.S.; Chow, W.T.L. Landscape configuration and urban heat island effects: Assessing the relationship between landscape characteristics and land surface temperature in Phoenix, Arizona. Landsc. Ecol. 2013, 28, 271-283. [CrossRef]

37. Kikon, N.; Singh, P.; Singh, S.K.; Vyas, A. Assessment of urban heat islands (UHI) of Noida City, India using multi-temporal satellite data. Sustain. Cities Soc. 2016, 22, 19-28. [CrossRef]

38. Lian, L.; Li, B.; Chen, Y.; Chu, C.; Qin, Y. Quantifying the effects of LUCCs on local temperatures, precipitation, and wind using the WRF model. Environ. Monit. Assess. 2017, 189. [CrossRef]

39. Ramdhoni, S.; Rushayati, S.B. Open green space development priority based on distribution of air temperature change in capital city of Indonesia, Jakarta. Procedia Environ. Sci. 2016, 33, 204-213. [CrossRef]

40. Ranagalage, M.; Estoque, R.C.; Murayama, Y. An urban heat island study of the Colombo Metropolitan Area, Sri Lanka, based on Landsat data (1997-2017). ISPRS Int. J. Geo-Inf. 2017, 6, 189. [CrossRef]

41. Senanayake, I.P.; Welivitiya, W.D.D.P.; Nadeeka, P.M. Remote sensing based analysis of urban heat islands with vegetation cover in Colombo city, Sri Lanka using Landsat-7 ETM+ data. Urban Clim. 2013, 5, 19-35. [CrossRef]

42. Kleerekoper, L.; Van Esch, M.; Salcedo, T.B. How to make a city climate-proof, addressing the urban heat island effect. Resour. Conserv. Recycl. 2012, 64, 30-38. [CrossRef]

43. Neema, M.N.; Ohgai, A. Multitype green-space modeling for urban planning using GA and GIS. Environ. Plan. B Plan. Des. 2013, 40, 447-473. [CrossRef]

44. Zhang, Y.; Murray, A.T.; Turner, B.L. Optimizing green space locations to reduce daytime and nighttime urban heat island effects in Phoenix, Arizona. Landsc. Urban Plan. 2017, 165, 162-171. [CrossRef]

45. Kusaka, H.; Suzuki-Parker, A.; Aoyagi, T.; Adachi, S.A.; Yamagata, Y. Assessment of RCM and urban scenarios uncertainties in the climate projections for August in the 2050s in Tokyo. Clim. Chang. 2016, 137, 427-438. [CrossRef]

46. Wang, J.; Huang, B.; Fu, D.; Atkinson, P.M.; Zhang, X. Response of urban heat island to future urban expansion over the Beijing-Tianjin-Hebei metropolitan area. Appl. Geogr. 2016, 70, 26-36. [CrossRef]

47. Kubota, T.; Lee, H.S.; Trihamdani, A.R.; Phuong, T.T.T.; Tanaka, T.; Matsuo, K. Impacts of land use changes from the Hanoi Master Plan 2030 on urban heat islands: Part 1. Cooling effects of proposed green strategies. Sustain. Cities Soc. 2017, 32, 295-317. [CrossRef] 
48. Lee, H.S.; Trihamdani, A.R.; Kubota, T.; Iizuka, S.; Phuong, T.T.T. Impacts of land use changes from the Hanoi Master Plan 2030 on urban heat islands: Part 2. Influence of global warming. Sustain. Cities Soc. 2017, 31, 95-108. [CrossRef]

49. Doan, V.Q. Projections of urban climate in the 2050s in a fast-growing city in Southeast Asia: The greater Ho Chi Minh City metropolitan area, Vietnam. Int. J. Climatol. 2018, 1-17. [CrossRef]

50. Li, H.; Zhou, Y.; Li, X.; Meng, L.; Wang, X.; Wu, S.; Sodoudi, S. A new method to quantify surface urban heat island intensity. Sci. Total Environ. 2018, 624, 262-272. [CrossRef]

51. Oke, T.R.; Mills, G.; Christen, A.; Voogt, J.A. Urban Climates; Cambridge University Press: Cambridge, UK, 2017; ISBN 9781139016476.

52. Voogt, J.A.; Oke, T.R. Thermal remote sensing of urban climates. Remote Sens. Environ. 2003, 86, 370-384. [CrossRef]

53. Weng, Q. Thermal infrared remote sensing for urban climate and environmental studies: Methods, applications, and trends. ISPRS J. Photogramm. Remote Sens. 2009, 64, 335-344. [CrossRef]

54. De Ridder, K.; Lauwaet, D.; Maiheu, B. UrbClim-A fast urban boundary layer climate model. Urban Clim. 2015, 12, 21-48. [CrossRef]

55. García-Díez, M.; Lauwaet, D.; Hooyberghs, H.; Ballester, J.; De Ridder, K.; Rodó, X. Advantages of using a fast urban canopy model as compared to a full mesoscale model to simulate the urban heat island of Barcelona. Geosci. Model Dev. Discuss. 2016, 1-17. [CrossRef]

56. Lauwaet, D.; De Nijs, T.; Liekens, I.; Hooyberghs, H.; Verachtert, E.; Lefebvre, W.; De Ridder, K.; Remme, R.; Broekx, S. A new method for fine-scale assessments of the average urban heat island over large areas and the effectiveness of nature-based solutions. One Ecosyst. 2018, 3, e24880. [CrossRef]

57. Skamarock, W.C.; Klemp, J.B.; Dudhi, J.; Gill, D.O.; Barker, D.M.; Duda, M.G.; Huang, X.-Y.; Wang, W.; Powers, J.G. A description of the advanced research WRF version 3. Tech. Rep. 2008, 113. [CrossRef]

58. Lazarova, L.; Kusaka, H. Study on the urban heat island in Sofia City: Numerical simulations with potential natural vegetation and present land use data. Sustain. Cities Soc. 2018, 40, 110-125. [CrossRef]

59. Li, H.; Zhou, Y.; Wang, X.; Zhou, X.; Zhang, H.; Sodoudi, S. Quantifying urban heat island intensity and its physical mechanism using WRF/UCM. Sci. Total Environ. 2019, 650, 3110-3119. [CrossRef]

60. Trusilova, K.; Früh, B.; Brienen, S.; Walter, A.; Masson, V.; Pigeon, G.; Becker, P. Implementation of an urban parameterization scheme into the regional climate model COSMO-CLM. J. Appl. Meteorol. Climatol. 2013, 52, 2296-2311. [CrossRef]

61. Kuchelmeister, G. Urban Forestry in the Asia-Pacific Region: Status and Prospects; Asia-Pacific Forestry Sector Outlook Study Working Paper; FAO Regional Office for Asia and the Pacific: Bangkok, Thailand, 1998.

62. Senanayake, I.P.; Welivitiya, W.D.D.P.; Nadeeka, P.M. Urban green spaces analysis for development planning in Colombo, Sri Lanka, utilizing THEOS satellite imagery - A remote sensing and GIS approach. Urban For. Urban Green. 2013, 12, 307-314. [CrossRef]

63. Perera, N.G.R. Climate-Sensitive Urban Public Space: A Sustainable Approach to Urban Heat Island Mitigation in Colombo, Sri Lanka; University of Moratuwa: Moratuwa, Sri Lanka, 2015.

64. De Ridder, K.; Schayes, G. The IAGL land surface model. J. Appl. Meteorol. 1997, 36, 167-182. [CrossRef]

65. Sharma, R.; Hooyberghs, H.; Lauwaet, D.; Ridder, K. Urban heat island and future climate change-Implications for Delhi's heat. J. Urban Heal. 2018. [CrossRef] [PubMed]

66. Bechtel, B.; Alexander, P.; Böhner, J.; Ching, J.; Conrad, O.; Feddema, J.; Mills, G.; See, L.; Stewart, I. Mapping local climate zones for a worldwide database of the form and function of cities. ISPRS Int. J. Geo-Inf. 2015, 4, 199-219. [CrossRef]

67. Stewart, I.D.; Oke, T.R. Local climate zones for urban temperature studies. Bull. Am. Meteorol. Soc. 2012, 93, 1879-1900. [CrossRef]

68. Perera, N.G.R.; Emmanuel, R. A “Local Climate Zone” based approach to urban planning in Colombo, Sri Lanka. Urban Clim. 2018, 23, 188-203. [CrossRef]

69. Ren, C.; Fung, J.C.-H.; Tse, J.W.P.; Wang, R.; Wong, M.M.F.; Xu, Y. Implementing WUDAPT product into urban development impact analysis by using WRF simulation result-A case study of the Pearl River Delta Region (1980-2010). In Proceedings of the 9th American Meteorological Society Annual Meeting 2017 (AMS2017), Seattle, WA, USA, 22-26 January 2017; pp. 22-26.

70. Best, M.J.; Grimmond, C.S.B. Analysis of the seasonal cycle within the first international urban land-surface model comparison. Bound.-Layer Meteorol. 2013, 146, 421-446. [CrossRef] 
71. Chai, T.; Draxler, R.R. Root mean square error (RMSE) or mean absolute error (MAE)? -Arguments against avoiding RMSE in the literature. Geosci. Model Dev. 2014, 7, 1247-1250. [CrossRef]

72. Emery, C.; Tai, E.; Yarwood, G. Enhanced meteorological modeling and performance evaluation for two texas ozone episodes. Env. Int. Corp. 2001, 235.

73. Oke, T.R. The Energetic Basis of The Urban Heat Island. Q. J. R. Meteorol. Soc. 1982, 108, 1-24. [CrossRef]

74. Gunawardena, K.R.; Wells, M.J.; Kershaw, T. Utilising green and bluespace to mitigate urban heat island intensity. Sci. Total Environ. 2017, 584-585, 1040-1055. [CrossRef]

75. Derkzen, M.L.; van Teeffelen, A.J.A.; Verburg, P.H. Quantifying urban ecosystem services based on high-resolution data of urban green space: An assessment for Rotterdam, the Netherlands. J. Appl. Ecol. 2015, 52, 1020-1032. [CrossRef]

76. Gkatsopoulos, P. A methodology for calculating cooling from vegetation evapotranspiration for use in urban space microclimate simulations. Procedia Environ. Sci. 2017, 38, 477-484. [CrossRef]

77. Li, H.; Wolter, M.; Wang, X.; Sodoudi, S. Impact of land cover data on the simulation of urban heat island for Berlin using WRF coupled with bulk approach of Noah-LSM. Theor. Appl. Climatol. 2017, 1-15. [CrossRef]

78. Oke, T.R. The urban energy balance. Prog. Phys. Geogr. 1988, 12, 471-508. [CrossRef]

79. Amorim, M.C.d.C.T.; Dubreuil, V. Intensity of urban heat islands in tropical and temperate climates. Climate 2017, 5, 91. [CrossRef]

80. Gharesifard, M.; Wehn, U.; van der Zaag, P. Towards benchmarking citizen observatories: Features and functioning of online amateur weather networks. J. Environ. Manag. 2017, 193, 381-393. [CrossRef] [PubMed]

(C) 2019 by the authors. Licensee MDPI, Basel, Switzerland. This article is an open access article distributed under the terms and conditions of the Creative Commons Attribution (CC BY) license (http:/ / creativecommons.org/licenses/by/4.0/). 